Language Variation and Change, 33 (2021), 267.

(c) The Author(s), 2021. Published by Cambridge University Press 0954-3945/21 $\$ 16.00$ This is an Open Access article, distributed under the terms of the Creative Commons Attribution licence (http:// creativecommons.org/licenses/by/4.0/), which permits unrestricted re-use, distribution, and reproduction in any medium, provided the original work is properly cited. doi:10.1017/S0954394521000156

\title{
Do Creoles conform to typological patterns? Habitual marking in Palenquero-Erratum
}

\author{
Hiram L. S Mith
}

https://doi.org/10.1017/S0954394521000053, Published by Cambridge University Press, 7 June 2021

In the original publication of this article (Smith, 2021), a production error caused some of the Examples to be misnumbered. The correct numbering is as follows:

- The two examples given on the eighth page of the article are examples (4) and (5).

- The examples given on the ninth page of the article are, in order, examples (6), (7), (8), (9), (10), and (11).

The other examples are correctly numbered in the original article.

The publisher sincerely apologizes for this error, which was not the fault of the author.

\section{REFERENCE}

Smith, Hiram L. (2021). Do Creoles conform to typological patterns? Habitual marking in Palenquero. Language Variation and Change. doi: 10.1017/S0954394521000053, 1-24. 